\title{
Development, Optimization and Absorption Mechanism of DHP107, Oral Paclitaxel Formulation for Single-Agent Anticancer Therapy
}

\author{
In-Hyun Lee, Jung Wan Hong, Yura Jang, \\ Yeong Taek Park and Hesson Chung \\ Korea Institute of Science and Technology \\ and Daehwa Pharmaceutical \\ Korea
}

\section{Introduction}

Paclitaxel, administered as intravenous infusion currently, is an effective anticancer drug belonging to the taxane family (Figure 1) and used in the treatment of a wide variety of cancers including breast and ovarian cancers (Rowinsky et al., 1995). Researchers have been looking for more effective and convenient ways to administer paclitaxel with less formulation-related toxicities than the commercially available formulations like Taxol ${ }^{\circledR}$ by Bristol-Meyers Squibb. It is well known that some of the limitations of the current formulation come from Cremophor EL, a polyoxyethylated castor oil. This particular component is known to cause hypersensitivity (Weiss et al., 1990), to be responsible for nonlinear pharmacokinetic behavior (Kearns et al., 1995; Gianni, 1995) and to cause paclitaxel precipitation oftentimes when diluted during the infusion process (Pfeifer, 1993). Formulations for paclitaxel and its analogs have been prepared in many different ways for various administration procedures (Kim et al., 2006; Xie et al., 2007; Sugahara et al., 2007; Singla et al., 2002; Hennenfent \& Govindan, 2006). Several years ago, Abraxane ${ }^{\circledR}$, a suspension of albumin nanoparticles containing paclitaxel, obtained approval to treat metastatic breast cancer patients (Ibrahim et al., 2002; Garber, 2004). Abraxane ${ }^{\circledR}$, a solvent-

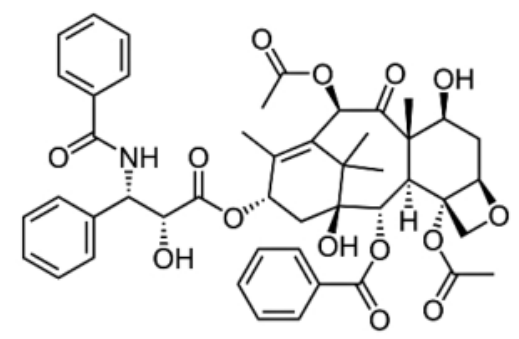

Fig. 1. Structure of paclitaxel 


\begin{tabular}{|c|c|c|c|c|c|}
\hline Formulation & $\begin{array}{c}\text { AUC } \\
(\mu \mathrm{g} h / \mathrm{ml})\end{array}$ & $\begin{array}{c}\text { Cmax } \\
(\mu \mathrm{g} / \mathrm{ml})\end{array}$ & $\begin{array}{c}\text { Dose } \\
(\mathrm{mg} / \mathrm{kg})\end{array}$ & $\begin{array}{l}\text { Rodent } \\
\text { species }\end{array}$ & Ref \\
\hline \multicolumn{6}{|l|}{ Without inhibitors } \\
\hline Taxol & $0.50\left(0-8^{*}\right)$ & 0.14 & 10 & mice & Sparreboom et al., 1997 \\
\hline Taxol & $0.37(0-4)$ & $0.13^{* * *}$ & 10 & mice & Bardelmeijer et al., 2004 \\
\hline Taxol & $1.89(0-\infty)$ & 0.11 & 50 & rat & Choi \& Li, 2005 \\
\hline Taxol & $0.41(0-6)$ & 0.12 & 10 & mice & Bardelmeijer et al., 2000 \\
\hline Cremophor/ethanol & $0.51(0-24)$ & 0.10 & 5 & mice & Asperen et al., 1998 \\
\hline Supersaturable-SEDDS & $0.44(0-\infty)$ & 0.28 & 10 & rat & Gao et al., 2003 \\
\hline SMEDDS & $0.81(0-24)$ & 0.05 & 2 & rat & Yang et al., 2004 \\
\hline SMEDDS & $0.97(0-24)$ & 0.05 & 10 & rat & Yang et al., 2004 \\
\hline microemulsion & $0.45(0-24)$ & 0.05 & 25 & rat & Woo et al., 2003 \\
\hline Suspension in Tween 80 & $1.65(0-24)$ & 0.11 & 40 & rat & Choi et al., 2004a, 2004b \\
\hline Lipid nanocapsule & $1.05(0-\infty)$ & 0.37 & 10 & rat & Peltier et al., 2006 \\
\hline \multicolumn{6}{|l|}{ With inhibitors } \\
\hline $\begin{array}{l}\text { Cremophor/Ethanol } \\
\text { +Cyclosporine A }\left(50^{* *}\right)\end{array}$ & $6.68(0-24)$ & 0.73 & 10 & mice & Asperen et al., 1998 \\
\hline $\begin{array}{l}\text { Supersaturable-SEDDS } \\
+ \text { cyclosporine A ( } 30)\end{array}$ & $1.05(0-\infty)$ & 0.31 & 10 & rat & Gao et al., 2003 \\
\hline SMEDDS+cyclosporine A (40) & $1.14(0-24)$ & 0.16 & 2 & rat & Yang et al., 2004 \\
\hline Taxol+verapamil (15) & $4.27(0-\infty)$ & 0.19 & 50 & rat & Choi \& Li, 2005 \\
\hline Microemulsion+KR-30031 (20) & $3.37(0-24)$ & 0.22 & 25 & rat & Woo et al., 2003 \\
\hline Surfactant mix + KR30031 (5) & $0.39(0-12)$ & 0.06 & 5 & rat & Kim et al., 2004 \\
\hline $\begin{array}{l}\text { Suspension in Tween } 80+ \\
\text { quercetin }(20)\end{array}$ & $5.00(0-24)$ & 0.28 & 40 & rat & Choi et al., 2004b \\
\hline Taxol+cyclosporine A (50) & $3.61(0-4)$ & $0.82^{* * *}$ & 10 & mice & Bardelmeijer et al., 2004 \\
\hline Taxol+PSC 833 (50) & $2.71(0-4)$ & $1.47^{* * *}$ & 10 & mice & Bardelmeijer et al., 2004 \\
\hline Taxol+GF120918 (25) & $1.39(0-4)$ & $0.55^{* * *}$ & 10 & mice & Bardelmeijer et al., 2004 \\
\hline Taxol+LY335979 (80) & $1.41(0-4)$ & $0.42^{* * *}$ & 10 & mice & Bardelmeijer et al., 2004 \\
\hline Taxol+R101933 (80) & $0.93(0-4)$ & $0.32^{* * *}$ & 10 & mice & Bardelmeijer et al., 2004 \\
\hline Taxol+GF120918 (25) & $2.65(0-10)$ & 0.77 & 10 & mice & Bardelmeijer et al., 2000 \\
\hline Taxol+PSC 833 (50) & & & & mice & Asperen et al., 1997 \\
\hline
\end{tabular}

* Time-interval used for the calibration of AUC,

** Dose of the inhibitor in $\mathrm{mg} / \mathrm{kg}$, and

*** Estimated concentration

Table 1. Mini-review: Selective pharmacokinetic data of paclitaxel after oral administration to rodents.

free formulation has a number of improved features such as shorter infusion time and no hypersensitivity without premedication (Garber, 2004).

Since an oral route would clearly be an attractive alternative to injection for patients as well as for medical personnel, there have been many attempts to prepare effective oral paclitaxel 
formulations. Paclitaxel, however, is known to be absorbed poorly in the gastrointestinal tract when administered orally (Sparreboom et al., 1997; Bardelmeijer et al., 2004; Choi \& Li, 2005; Bardelmeijer et al., 2000). The reasons for poor absorption were identified to be drug metabolism by cytochrome P450 (CYP) and the existence of the efflux system, such as Pglycoproteins in intestinal epithelial cells and liver (Schellens et al., 2000). Tellingen and coworkers identified that the epithelial efflux system composed of P-glycoproteins lowered the drug absorption by demonstrating that orally administered paclitaxel can be absorbed well in mice with a homozygously disrupted mdr1a gene (mdr1a(-/-) mice) (Sparreboom et al., 1997). Proof-of-concept experiments in mice and man have also shown that oral absorption of paclitaxel could be increased dramatically by concomitant administration of a P-glycoprotein inhibitor, cyclosporine A (Schellens et al., 2000; Asperen et al., 1998; Meerum Terwogt et al., 1999). Other P-glycoprotein blockers that could also serve as CYP 450 inhibitors also boosted the oral absorption of paclitaxel (Sparreboom et al., 1997; Bardelmeijer et al., 2004; Choi \& Li, 2005; Kim et al., 2004; Asperen et al., 1997). Formulations that do not contain Cremophor EL, that could lower the in vivo toxicity and increase solubilization of paclitaxel, were shown to deliver paclitaxel efficiently via oral administration especially when P-glycoprotein inhibitors were given simultaneously (Kim et al., 2004; Gao et al., 2003; Yang et al., 2004; Woo et al., 2003; Choi et al., 2004a, 2004b; Peltier et al., 2006).

In Table 1, we reviewed the literature on oral paclitaxel formulations and summarized the pharmacokinetic data of paclitaxel obtained from the small-animal experiments (FVB mice and Sprague-Dawley rats). In the Table, we have listed Area under the plasma concentration vs. time curve (AUC) value, maximum drug concentration in the blood $\left(\mathrm{C}_{\max }\right)$ and oral dose. One has to keep in mind that the data from different papers may not be compared directly since the AUC values in the literature were estimated for different time intervals and drug doses while the pharmacokinetics of paclitaxel is known to be non-linear (Kearns et al., 1995; Gianni, 1995). Different time intervals could not be normalized due to lack of information in the pharmacokinetics data to make such estimations and thus must be viewed with caution. Another important point to note is that Cremophor EL in $\operatorname{Taxol}^{\circledR}$, used for intravenous administration in some cases (Sparreboom et al., 1997; Bardelmeijer et al., 2004; Asperen et al., 1998; Gao et al., 2003; Yang et al., 2004; Peltier et al., 2006), causes nonlinear pharmacokinetic behavior (Sparreboom et al., 1996). Also, paclitaxel dissolved in Tween 80, also used for intravenous controls in others (Choi \& Li, 2005; Bardelmeijer et al., 2000; Woo et al., 2003; Choi et al., 2004a, 2004b), does show linear pharmacokinetic behavior, but has ca. 5 10 times lower AUC values when compared to diluted Taxol ${ }^{\circledR}$ (Sparreboom et al., 1996). For these reasons, it was impossible to list the bioavailability values in Table 1.

In the past several years, we have been developing paclitaxel formulations with biocompatible oils, lipids and emulsifiers (Lee et al. Hong et al., 2004; I. H. Lee et al., 2005; S. J. Lee et al., 2005). Paclitaxel dissolved in a stable Lipiodol formulation was shown to retard the growth of hepatocellular carcinoma efficiently when transcatheter arterial chemoembolization was performed in rabbits (Yoon et al., 2003). Also, a paclitaxel formulation prepared with monoolein, tricaprylin and Tween 80 was mucoadhesive when given intravesically (S. J. Lee et al., 2005). Paclitaxel in this formulation penetrated to lamina propria and close to the muscle layer of the bladder while the paclitaxel concentration was low throughout the depth of the bladder tissue when Taxol ${ }^{\circledR}$ was used. We also have shown 
that this mucoadhesive formulation can deliver paclitaxel effectively when given by oral route without additional active pharmaceutical ingredient as an absorption enhancer (Lee et al., 2004; Hong et al., 2004; I. H. Lee et al., 2005, Shin et al., 2009). As an endeavor to formulate more efficient oral paclitaxel formulations, we have prepared oil-based paclitaxel formulations with monoolein, saturated triglycerides and emulsifiers. Monoolein was included in the formulation as a main ingredient due to its high bioadhesiveness (Nielsen et al., 1998) and its ability to release the encapsulated drug in a controlled fashion (Clogston et al., 2005a, 2005b). Triglycerides were added since they can solubilize paclitaxel efficiently (Kan et al., 1999). To access the effectiveness of the formulations, pharmacokinetic and antitumor efficacy studies were performed in mice models.

\section{Materials and methods}

\subsection{Materials}

Distilled monoolein (RYLOTM MG 19, > $90 \%$ pure) was purchased from Danisco Ingredients, Denmark. Paclitaxel was obtained from Samyang Genex (Korea) and Indena S.P.A. (Italy). Cremophor EL, Tween 80 and triglycerides (triacetin, tributyrin, tricaproin, tricaprylin, tricaprin and trilaurin) were purchased from Sigma Chemical Co. (St. Louis, $\mathrm{MO})$.

\subsection{Preparation of oral paclitaxel formulations}

The compositions of the oral paclitaxel formulations used in the experiments are summarized in Tables 2 and 3. Paclitaxel formulations with various triglycerides (Table 2) were prepared as follows: Paclitaxel in amorphous form was dissolved completely at 10 $\mathrm{mg} / \mathrm{ml}$ in mixtures of oils consisting of monoolein, triglycerides and Tween 80 by sonication for $30 \mathrm{~s}$. Some of the oral paclitaxel formulations were semi-solid or solid wax at ambient temperatures with the melting points of $30 \sim 50{ }^{\circ} \mathrm{C}$, and therefore had to be warmed before oral feeding.

In Table 3, Paclitaxel, amorphous or crystalline, was dissolved completely in excess amount of methylene chloride and mixed subsequently with tricaprylin. Methylene chloride was evaporated completely to prepare paclitaxel/tricaprylin solution by vacuum evaporation (BUCHI rotavapor R-200, Germany) at $40{ }^{\circ} \mathrm{C}$ for $1 \mathrm{~h}$. The content of methylene chloride was determined by gas chromatography and was less than $100 \mathrm{ppm}$ in the paclitaxel/tricaprylin solution. Monoolein and Tween 80 were added to the paclitaxel/tricaprylin solution and mixed completely by sonication for $30 \mathrm{~s}$. A formulation that does not contain paclitaxel, eG2, was also prepared for control. The oral paclitaxel formulations were semi-solid wax with the melting temperature of $33 \sim 35^{\circ} \mathrm{C}$, and were warmed to body temperature before feeding.

Dispersions of the oral paclitaxel formulations (G8, G9, and G10) were prepared by adding 2.3 times (by volume) of distilled water or syrup to the formulation G2 (also will be referred to as DHP107) and by vortexing or sonicating for $1 \mathrm{~min}$.

\subsection{Animals}

Male ICR and Balb/c athymic mice, 7 weeks old, were purchased from Orient Bio Co. (Seoul, Korea) and Japan SLC (Japan), respectively, and maintained 1 week. Animal care 
and handling followed institutional guidelines (Korea Institute of Science and Technology). Mice were maintained with free access to food and water under a 12-h light/dark cycle.

\subsection{Differential scanning calorimetry}

Differential scanning calorimetry (DSC) was performed to obtain the heating thermograms of paclitaxel and the formulations in Table 2 (DSC 821e, Mettler Toledo, Columbus, $\mathrm{OH}$, equipped with Intracooler, Haake EK90/MT, Haake, Denmark) at a heating scan rate of 5 ${ }^{\circ} \mathrm{C} / \mathrm{min}$. Scans were made with samples contained in hermetically sealed aluminum crucibles (ME-27331, Mettler Toledo). Initial heating scans were reported for paclitaxel and the formulations in Table 2. In case of the formulations, thermal history did not alter the heating thermograms if the samples were cooled to $-20^{\circ} \mathrm{C}$ before reheating.

\subsection{Determination of the particle size in the dispersion}

The average particle size in the dispersions G8, G9 and G10 in Table 3 was determined by quasielastic laser light scattering with a Malvern Zetasizer ${ }^{\circledR}$ (Malvern Instruments Limited, England). The dispersions were diluted by 300 times in water before the measurement. The size determination was repeated 3 times/sample. The average size and the size distribution were estimated from the log-normal size distribution function as shown previously (Chung et al., 2001)

\subsection{Oral administration of paclitaxel formulations}

Paclitaxel formulations in Tables 2 and 3 were liquefied at $37 \sim 50{ }^{\circ} \mathrm{C}$ and administered orally at doses of $25,50,75$, and $100 \mathrm{mg} / \mathrm{kg}$ with a blunt needle via the esophagus into the stomach. The male ICR mice were fasted for $8 \mathrm{~h}$ prior to oral administration except for the group G3. Taxol ${ }^{\circledR}$ prepared by dissolving paclitaxel in an equivolume mixture of Cremophor EL and ethanol at $6 \mathrm{mg} / \mathrm{ml}\left(\operatorname{Taxol}^{\circledR}\right)$ was diluted by 6 times with the saline solution, and was administered via bolus tail-vein injection at a dose of $10 \mathrm{mg} / \mathrm{kg}$ as a positive control. Blood samples were collected at various time points $(n=6)$ after drug administration, and were stored at $-70{ }^{\circ} \mathrm{C}$ until analysis.

\subsection{Analysis of paclitaxel concentrations in blood}

Whole blood $(200 \mu \mathrm{l})$ was spiked with irbesartan $(0.5 \mu \mathrm{g} / \mathrm{ml}$; internal standard $)$, mixed and added to acetonitrile $(400 \mu \mathrm{l})$ to precipitate proteins. After centrifugation at $14,000 \mathrm{RCF}$ for $20 \mathrm{~min}$, the supernatant was collected and mixed with the mobile phase to adjust the volume to $0.6 \mathrm{ml}$. Ten microliters of the blood was injected into the LC/MS/MS system. Analyses were performed with a Thermo-Finnigan Discovery Max LC/MS/MS (San Jose, CA, USA). The LC system was performed at $35{ }^{\circ} \mathrm{C}$ on a Capcellpak C18 column $(150$ X 2.0 mm i.d., $5 \mu \mathrm{m}$ particle size, Shisheido, Japan) equipped with a Zorbax SB-Aq (12.5 X $2.1 \mathrm{~mm}$ i.d.) guard column. The mobile phase consisted of $55 \%$ acetonitrile, $0.08 \%$ formic acid and $44.92 \%$ water, and the flow rate was $0.4 \mathrm{ml} / \mathrm{min}$. The instrument was operated in SRM mode (positive ion), monitoring the ion transitions from $\mathrm{m} / \mathrm{z} 854 \rightarrow 285$ (paclitaxel) and $\mathrm{m} / \mathrm{z} 429 \rightarrow 195$ (internal standard). The paclitaxel LC/MS/MS assay was linear over the range of $2 \sim 1000 \mathrm{ng} / \mathrm{ml}$ with a lower quantitation limit of $2 \mathrm{ng} / \mathrm{ml}$ in blood. Paclitaxel 
concentrations in blood were calculated based on a standard curve of paclitaxel in blank pooled animal blood with the internal standard.

\subsection{Tumor experiment}

Suspension of NCI-H358 human non-small cell lung cancer cells $\left(1.2 \times 10^{7}\right.$ cells $/$ mouse), purchased from American Type Culture Collection (ATCC, Manassas, VA), was injected subcutaneously to the dorsal flank of male Balb/c athymic mice ( 8 weeks). When the tumor volume (length $\times$ width $\times$ height $\times 0.5236$ ) reached $c a .100 \mathrm{~mm}^{3}$ in 10 days after the injection (day 0$)$, the experimental groups were divided at random into three groups $(n=8)$. On days 1, 2, 3, 4 and 5, G2 formulation (DHP107) was administered orally at a dose of $50 \mathrm{mg} / \mathrm{kg}$ (G2). For controls, mice injected intravenously with diluted Taxol ${ }^{\circledR}$ (Taxol, $10 \mathrm{mg} / \mathrm{kg}$ ) and fed orally with the vehicle only (eG2) on days 1, 2, 3, 4 and 5 were also observed.

\subsection{Characterization of crystalline forms of paclitaxel}

X-Ray diffraction (XRD) measurements were made by using an x-ray diffractometer (D8 Discover, Bruker, Karlsruhe, Germany) with the general area detector diffraction system (GADDS, Bruker, Karlsruhe, Germany). The $\mathrm{Cu} \mathrm{K}$ a radiation of wavelength $1.542 \AA$ was provided by the x-ray generator (FL CU $4 \mathrm{KE}$, Bruker, Karlsruhe, Germany) operating at 40 $\mathrm{kV}$ and $45 \mathrm{~mA}$. Sample-to-detector distance was $300 \mathrm{~mm}$. Exposure time was $1 \sim 5 \mathrm{~h}$. To avoid air scattering, the beam path was filled with helium. The surface morphology of paclitaxel was observed by scanning electron microscopy (SEM; Hitachi S-2460N, Japan) at an accelerating voltage of $15 \mathrm{kV}$ after Pt/Au sputter coating (Hitachi E1010 Ion sputter, Japan).

\section{Results}

\subsection{Characterization of crystalline forms of paclitaxel}

Crystalline forms of paclitaxel obtained from different sources were determined by DSC, $\mathrm{x}$ ray diffraction and scanning electron microscopy. Paclitaxel can exist as different polymorphs having distinct physical properties, which could influence the manufacturing process of the formulations (Liggins et al., 1997; Lee et al., 2001). Paclitaxel obtained from Samyang Genex (Genexol, Korea) had the glass transition temperature at $150{ }^{\circ} \mathrm{C}$ and an exothermic transition at $220{ }^{\circ} \mathrm{C}$ whereas paclitaxel obtained from Indena had the melting transition at $210{ }^{\circ} \mathrm{C}$ as shown in Figure 2, corresponding to amorphous and anhydrous crystalline forms, respectively, as shown in the literature (Liggins et al., 1997). X-ray diffraction data revealed the differences in the crystallinity of paclitaxel. Diffraction pattern of Genexol showed two broad scattering peaks centered at $c a .10^{\circ}$ and $20^{\circ}$ characteristic of the amorphous form. Paclitaxel from Indena, on the other hand, revealed a pattern with strong and sharp diffraction peaks at $5.7^{\circ}$ and $12.6^{\circ}$ indicating a highly ordered structure. Surface morphology was also visualized by SEM. Genexol was observed to be in the powder form with highly contoured surfaces. We note that the grain size or the surface area of the powder varied depending on the lot numbers of Genexol (data not shown). For instance, Genexol 131 was composed of powders with wrinkled surfaces whereas Genexol 183 contained smooth and round particles as well when observed by SEM. Needle-like crystals were observed for paclitaxel from Indena. Based on DSC, XRD and SEM experiments, 


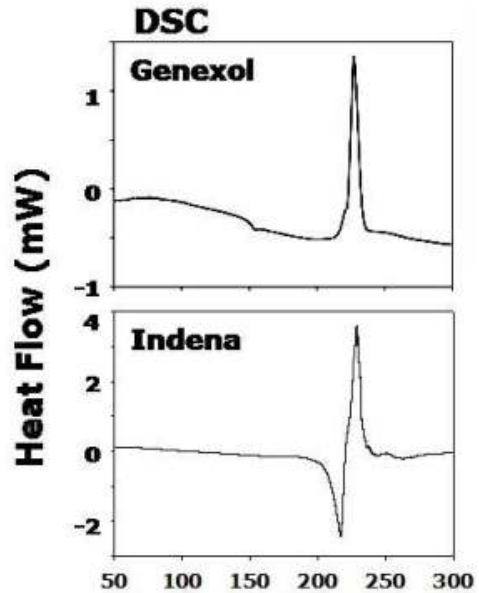

Temperature $\left({ }^{\circ} \mathrm{C}\right)$

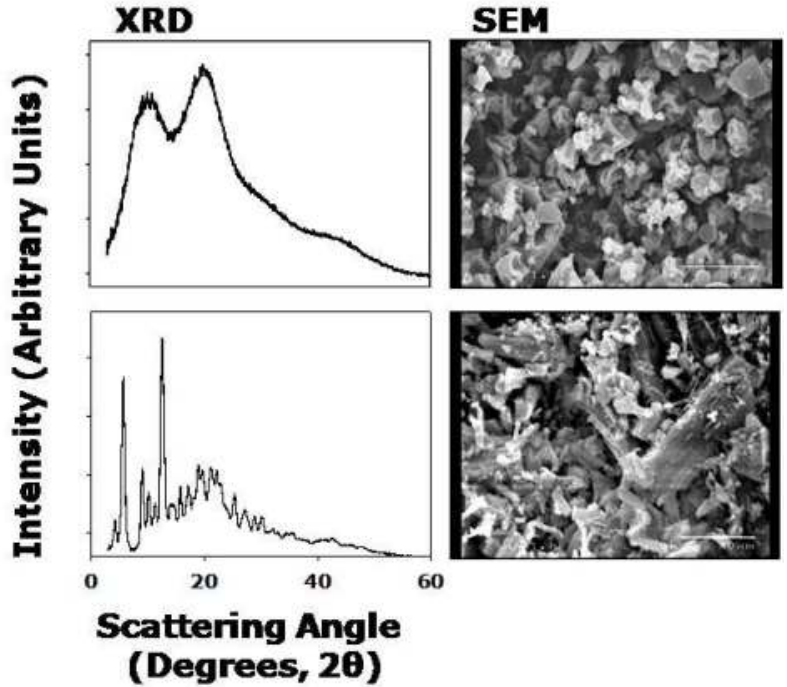

Fig. 2. Differential Scanning calorimetry, x-ray diffraction and scanning electron microscopy of paclitaxel obtained from of Genexol (upper panels) and Indena (lower panels).

we confirmed that Paclitaxel from Samyang Genex and Indena were in amorphous and anhydrous crystalline forms, respectively.

Due to the differences in the grain size and crystalline forms, we used two different procedures in preparing the oral formulations. Genexol 131 was readily soluble in all of the lipid mixtures in Table 2 when sonicated for $c a .30 \mathrm{~s}$. Genexol 183, which had larger grains than Genexol 131, and paclitaxel from Indena did not dissolve in the lipid mixture. In these cases, paclitaxel was solubilized completely in the mixture of methylene chloride and triglyceride. Methylene chloride was evaporated completely from the mixture before other ingredients were added to prepare the formulations in Table 3.

\subsection{Physical properties of oral paclitaxel formulations}

Oral paclitaxel formulations existed as oil/wax mixtures at ambient temperatures, but formed clear liquid at $37^{\circ} \mathrm{C}$ except for the Formulation T12 (Table 2). The T12 formulation existed as solid wax at ambient temperatures. Thermal behavior of the formulations containing different triglycerides was investigated by performing DSC (Figure 3A).

The thermograms were identical with or without paclitaxel in the formulations, and those with paclitaxel are shown in the Figure. Tween 80, liquid at room temperature, did not show any phase transition in the temperature range from 0 to $60{ }^{\circ} \mathrm{C}$. Lamellar crystalline-to-fluid isotropic, or the chain melting, phase transition of monoolein was observed at $32{ }^{\circ} \mathrm{C}$, which is similar to the values reported for pure monoolein (Briggs et al., 1996; Qiu \& Caffrey, 2000) or Myverol 18-99K (Clogston, 2000) in the literature. The chain melting transition of monoolein for the monoolein/Tween 80 (55.0:16.5 by weight) mixture was observed at $26{ }^{\circ} \mathrm{C}$, since Tween 80 lowered the transition temperature of monoolein. In the formulations T2, T4 and T6, only the chain melting transition of monoolein was observed because triacetin, 


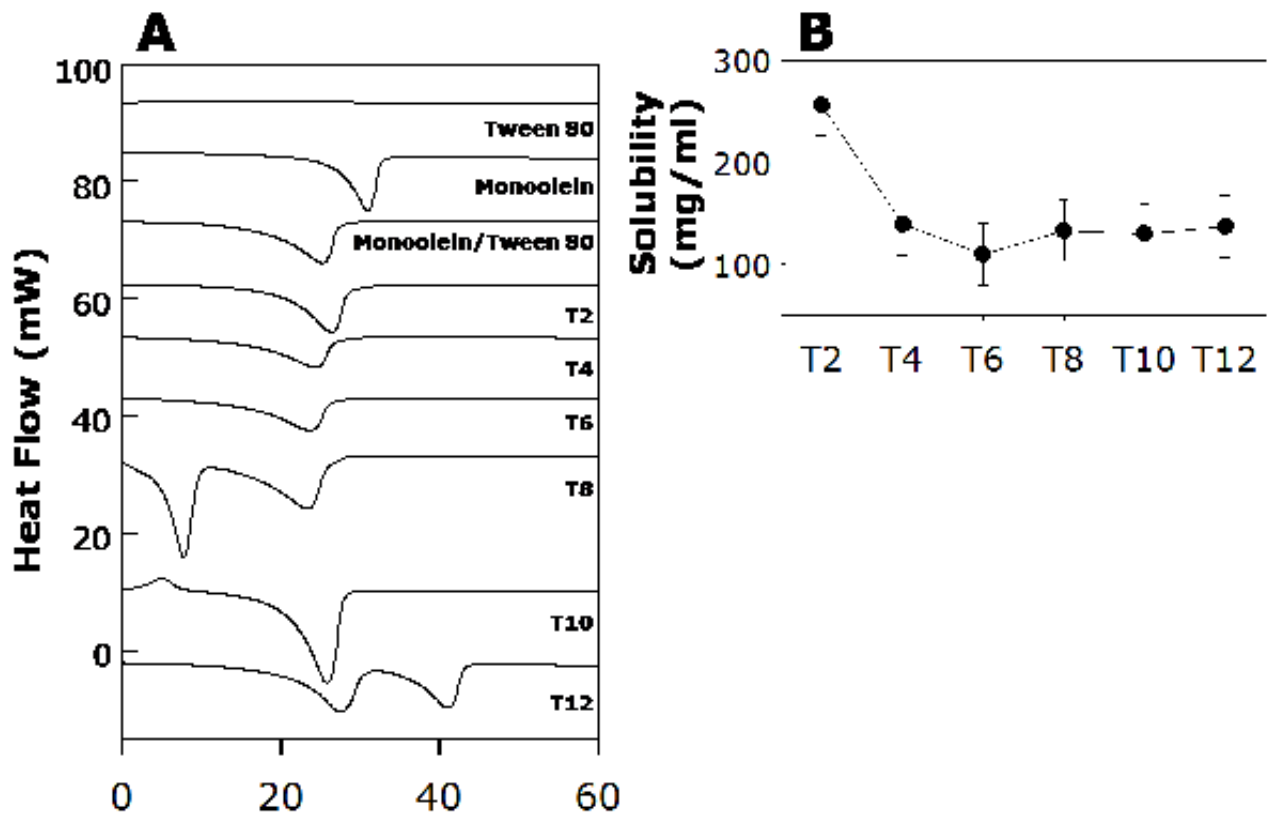

Fig. 3. A) Heating thermograms obtained from the formulations prepared with different triglycerides (T2 T12, in Table 2), Tween 80, monoolein and monoolein/Tween 80 mixture (55.0:16.5 by weight). The concentration of paclitaxel was $1 \%(\mathrm{w} / \mathrm{w})$ in all formulations. B) Solubility of paclitaxel in the formulations containing monoolein, triglyceride and Tween 80 at 55.0:27.5:16.5 by weight at $37^{\circ} \mathrm{C}$.

tributyrin and tricaprin were immiscible with solid monoolein. We could identify visually the phase separation of these triglycerides below ca. $26^{\circ} \mathrm{C}$. In $\mathrm{T} 8$ formulation, chain melting transitions of tricaprylin and monoolein were observed at 8 and $23{ }^{\circ} \mathrm{C}$, respectively. In case of T10 formulation, single transition peak from the melting transition of the eutectic mixture of monoolein and tricaprin $\left(2: 1\right.$ by weight) was observed at $26{ }^{\circ} \mathrm{C}$ (Roh et al., 2004). The chain melting transitions of monoolein and trilaurin were observed at 32 and $41{ }^{\circ} \mathrm{C}$, respectively, for $\mathrm{T} 12$ formulation. Results show that all the formulations existed as solid/liquid or solid/solid mixtures at room temperature, but transforms into the singlephase liquid when heated to the body temperature for T2 $\sim \mathrm{T} 10$ formulations or above $45^{\circ} \mathrm{C}$ for T12 formulation. Paclitaxel was solubilized well inside all of the formulations in the temperature range studied when observed by polarized light microscopy (data not shown).

\subsection{Solubility of paclitaxel in oral formulations}

The solubility of paclitaxel in the oral formulations with different triglycerides was determined at $37{ }^{\circ} \mathrm{C}$. Mixtures of monoolein/triglyceride/Tween 80 were prepared at 55.0:27.5:16.5 by weight and warmed to melt. Paclitaxel in powder form (Genexol, Samyang Genex, lot G131) was added stepwise to these mixtures until undissolved aggregates were observed. The mixtures were vortexed for $10 \mathrm{~s}$ and sonicated for $3 \mathrm{~min}$ after each addition at $37^{\circ} \mathrm{C}$. The formulation containing trilaurin was heated to $60^{\circ} \mathrm{C}$ and cooled to $37^{\circ} \mathrm{C}$ to obtain 
the undercooled liquid for the measurement. Solubility of paclitaxel was ca. $250 \pm 30 \mathrm{mg} / \mathrm{ml}$ for the formulation containing triacetin, but was $c a .120 \pm 40 \mathrm{mg} / \mathrm{ml}$ for those with other triglycerides (Figure 3B).

\subsection{Pharmacokinetics of oral paclitaxel administration and intravenous Taxol injection}

Oral paclitaxel formulations were warmed to body temperature and administered to male ICR mice. We note that not the dispersions but the oily formulations were administered, and no other active pharmaceutical ingredients were given to the animals. Diluted Taxol ${ }^{\circledR}$ was given intravenously as a control. Paclitaxel concentration in blood after oral administration of formulation G2 (DHP107, paclitaxel dose of $50 \mathrm{mg} / \mathrm{kg}$ ) and intravenous injection of Taxol $^{\circledR}(10 \mathrm{mg} / \mathrm{kg})$ was plotted as a function of time in Figure $4 \mathrm{~A}$ (normal scale) and Figure 4B (logarithmic scale). Paclitaxel concentration in blood was $60.2 \mu \mathrm{g} / \mathrm{ml}$ in $1 \mathrm{~min}$ after intravenous injection, and dropped to $c a .6 .2$ and $0.8 \mu \mathrm{g} / \mathrm{ml}$ and in 0.5 and $3 \mathrm{~h}$, respectively. Paclitaxel concentration in blood increased and became 1.2 and $2.1 \mu \mathrm{g} / \mathrm{ml}$ at 1 and $3 \mathrm{~h}$, respectively, after oral administration of DHP107. Pharmacokinetic parameters are listed in Table 2. The bioavailability $\left[(\mathrm{BA})(\%)=\left(\mathrm{AUC}_{\text {oral }} / \mathrm{AUC}_{\mathrm{iv}}\right) \cdot\left(\right.\right.$ Dose $_{\mathrm{iv}} /$ Dose $\left.\left._{\text {oral }}\right) \times 100\right]$ of DHP107 in mice was $c a .14 \%$. Since the plasma concentration of paclitaxel above a threshold value of $85.3 \mathrm{ng} / \mathrm{ml}$ (dashed line in Figure 4B) was proven to be pharmacologically active, DHP107 could be effective for more than $8 \mathrm{~h}$ (Huizing et al., 1997).

\begin{tabular}{ccccc}
\hline Treatment group & Triglyceride type & $\mathrm{T}_{\max }(\mathrm{h})$ & $\mathrm{C}_{\max }(\mu \mathrm{g} / \mathrm{ml})$ & $\begin{array}{c}\mathrm{AUC}_{0-9} \\
(\mu \mathrm{g} \cdot \mathrm{h} / \mathrm{ml})\end{array}$ \\
\hline T2 & Triacetin & 3 & 0.4 & 1.6 \\
T4 & Tributyrin & 3 & 1.5 & 5.4 \\
T6 & Tricaproin & 3 & 3.1 & 12.0 \\
T8 & Tricaprylin & 1 & 2.7 & 8.9 \\
T10 & Tricaprin & 1 & 2.2 & 8.4 \\
T12 & Trilaurin & 1 & 1.5 & 4.9 \\
\hline
\end{tabular}

Table 2. Pharmacokinetic parameters of paclitaxel after oral administration ( $50 \mathrm{mg} / \mathrm{kg}$ dose) of the formulations containing different triglycerides to Balb/c mice. The composition of the formulations was paclitaxel:monoolein:triglyceride:Tween $80=1.0: 55.0: 27.5: 16.5$ by weight.

\subsection{Oral administration of formulations with different triglycerides}

Paclitaxel formulations prepared with various triglycerides (paclitaxel: monoolein: triglyceride:Tween $80=1.0: 55.0: 27.5: 16.5$ by weight) were administered orally at $50 \mathrm{mg} / \mathrm{kg}$ dose to male ICR mice (Table 2, Figure 4C). AUC values were $12.1 \pm 2.6,8.9 \pm 1.8$ and $8.4 \pm$ $2.7 \mu \mathrm{g} \cdot \mathrm{h} / \mathrm{ml}$ for T6, T8 and T10 groups, respectively, with no statistical differences $(\mathrm{p}<0.15$ by Student $t$-test). In case of T2, T4 and T12 groups, AUC of paclitaxel was $1.6 \pm 0.5(\mathrm{p}<0.003$ compared the AUC with T6 formulation), $5.4 \pm 0.7(\mathrm{p}<0.01)$ and $4.9 \pm 1.6 \mu \mathrm{g} \cdot \mathrm{h} / \mathrm{ml}(\mathrm{p}<0.01)$, respectively. Maximum concentration of paclitaxel in blood $\left(\mathrm{C}_{\max }\right)$ was also the highest for the formulation with tricaproin (T6) and was $3.2 \pm 0.7 \mu \mathrm{g} \cdot \mathrm{h} / \mathrm{ml}$. Interestingly, the time to reach $\mathrm{C}_{\max }\left(\mathrm{T}_{\max }\right)$ was $3 \mathrm{~h}$ for the formulations with shorter chain triglycerides (T2, $\mathrm{T} 4$ and T6) and $1 \mathrm{~h}$ for T8, T10 and T12 groups. 


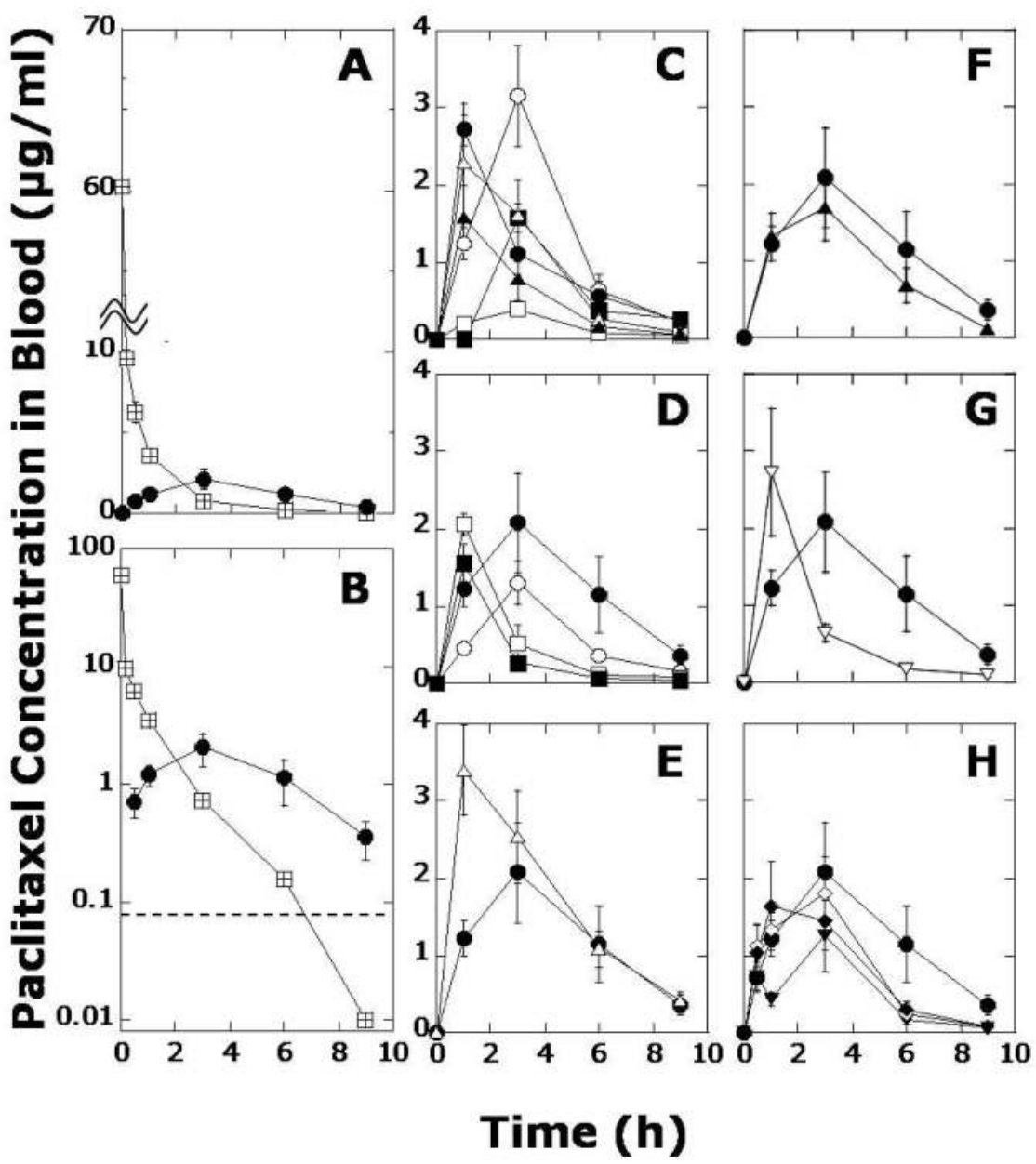

Fig. 4. Mean blood concentration of paclitaxel after intravenous administration of Taxol ${ }^{\circledR}$ and administration of oral formulations. Comparison between intravenous Taxol $(\boxplus, 10$ $\mathrm{mg} / \mathrm{kg}$ ) and oral DHP107 (G2,, $50 \mathrm{mg} / \mathrm{kg}$ ) is shown in normal (A) and logarithmic (B) scales. The dashed line in B) indicates the pharmacologically effective concentration (85.3 $\mathrm{ng} / \mathrm{ml}$ ). Oral administration of paclitaxel formulations C) with different triglycerides (T2: $\square$, T4: $\mathbf{\square}, \mathrm{T} 6: \bigcirc, \mathrm{T} 8: \bullet, \mathrm{T} 10: \triangle, \mathrm{T} 12: \mathbf{\Delta}), \mathrm{D})$ with different paclitaxel contents (G1: $\bigcirc, 5 \mathrm{mg}$ paclitaxel/ml formulation, G2, DHP107: $, 10 \mathrm{mg} / \mathrm{ml}, \mathrm{G} 3: \square, 15 \mathrm{mg} / \mathrm{kg}$, G4: $\square, 20 \mathrm{mg} / \mathrm{ml}$ ), E) under the fasting (G2, DHP107: $)$ and non-fasting (G5: $\triangle$ ) conditions, F) prepared with crystalline (G6: $\boldsymbol{\Delta}$ ) and amorphous (G2, DHP107: $)$ paclitaxel, G) with (G2, DHP107: $)$ ) or without $(G 7: \nabla)$ Tween 80 , and $H$ ) dispersed in syrup (G8: $\boldsymbol{\nabla}$ ) or in water (G9: $\diamond)$ by vortexing and in water by sonication (G10: $\bullet$ ) or given per se (G2, DHP107: $\bullet$ ). The oral dose of paclitaxel was $50 \mathrm{mg} / \mathrm{kg}$ except for G1 (25 mg/kg), G3 (75 mg/kg) and G4 (100 $\mathrm{mg} / \mathrm{kg})$. 
Development, Optimization and Absorption Mechanism of

\begin{tabular}{|c|c|c|c|c|c|c|c|c|c|c|c|}
\hline \multirow{2}{*}{$\begin{array}{l}\text { Treatment } \\
\text { group }\end{array}$} & \multirow{2}{*}{$\begin{array}{l}\text { Paclitaxel } \\
\text { Dose } \\
(\mathrm{mg} / \mathrm{kg})\end{array}$} & \multicolumn{6}{|c|}{ Composition [\%(w/w)] } & \multirow{2}{*}{$\begin{array}{l}\mathrm{T}_{\max } \\
(\mathrm{h})\end{array}$} & \multirow{2}{*}{$\begin{array}{c}\mathrm{C}_{\max } \\
(\mu \mathrm{g} / \mathrm{ml})\end{array}$} & \multirow{2}{*}{$\begin{array}{c}\mathrm{AUC}_{0-9} \\
(\mu \mathrm{gh} \\
/ \mathrm{ml})\end{array}$} & \multirow{2}{*}{$\begin{array}{l}\text { Crystallinity } \\
\text { of paclitaxel }\end{array}$} \\
\hline & & Paclitaxel & Monoolein & Tricaprylin & $\begin{array}{l}\text { Tween } \\
80\end{array}$ & $\begin{array}{c}\text { Cremophor } \\
\text { EL }\end{array}$ & Ethanol & & & & \\
\hline G1 & 25 (p.o.) & 0.5 & 55.5 & 27.5 & 16.5 & - & - & 3 & 1.3 & 5.2 & Amorphous \\
\hline $\begin{array}{c}\text { G2 } \\
\text { (DHP107) }\end{array}$ & 50 (р.o.) & 1.0 & 55.0 & 27.5 & 16.5 & - & - & 3 & 2.0 & 11.0 & Amorphous \\
\hline G3 & 75 (р.o.) & 1.5 & 54.5 & 27.5 & 16.5 & - & - & 1 & 2.0 & 4.7 & Amorphous \\
\hline G4 & 100 (p.o.) & 2.0 & 54.0 & 27.5 & 16.5 & - & - & 1 & 1.5 & 3.1 & Amorphous \\
\hline $\begin{array}{c}\text { G5 } \\
\text { (DHP107, } \\
\text { Non- } \\
\text { fasting) }\end{array}$ & 50 (p.o.) & 1.0 & 55.0 & 27.5 & 16.5 & - & - & 1 & 3.4 & 15.3 & Amorphous \\
\hline G6 & 50 (p.o.) & 1.0 & 55.0 & 27.5 & 16.5 & - & - & 3 & 1.6 & 8.3 & Crystalline \\
\hline G7 & 50 (р.o.) & 1.0 & 66.0 & 33.0 & - & - & - & 1 & 2.7 & 6.3 & Amorphous \\
\hline eG2 & 0 (p.o.) & 0.0 & 56.0 & 27.5 & 16.5 & - & - & - & - & - & - \\
\hline Taxol & 10 (i.v.) & 0.6 & - & - & - & 57.0 & 42.4 & 0.016 & 60.2 & 15.7 & Amorphous \\
\hline \multirow{2}{*}{$\begin{array}{l}\text { Treatment } \\
\text { group }\end{array}$} & \multirow{2}{*}{$\begin{array}{l}\text { Paclitaxel } \\
\text { Dose } \\
(\mathrm{mg} / \mathrm{kg})\end{array}$} & \multicolumn{6}{|c|}{ Composition [\%(w/w)] } & $\begin{array}{l}\mathrm{T}_{\max } \\
(\mathrm{h})\end{array}$ & $\begin{array}{c}\mathrm{C}_{\max } \\
(\mu \mathrm{g} / \mathrm{ml})\end{array}$ & $\begin{array}{l}\mathrm{AUC}_{0-9} \\
(\mu \mathrm{gh} \\
/ \mathrm{ml})\end{array}$ & \multirow{2}{*}{$\begin{array}{l}\text { Dispersing } \\
\text { method }\end{array}$} \\
\hline & & Paclitaxel & Monoolein & Tricaprylin & $\begin{array}{l}\text { Tween } \\
80\end{array}$ & Syrup & Water & & & & \\
\hline G8 & 50 (p.o.) & 0.3 & 16.2 & 8.0 & 5.5 & 70 & - & 3 & 1.2 & 4.6 & Vortex \\
\hline G9 & 50 (р.o.) & 0.3 & 16.2 & 8.0 & 5.5 & - & 70 & 3 & 1.8 & 7.5 & Vortex \\
\hline G10 & 50 (p.o.) & 0.3 & 16.2 & 8.0 & 5.5 & - & 70 & 1 & 1.6 & 7.1 & Sonication \\
\hline
\end{tabular}

Table 3. Compositions of paclitaxel formulations and pharmacokinetic parameters of paclitaxel after intravenous or oral administration in Balb/c mice.

\subsection{Oral administration of formulations with different paclitaxel contents}

We prepared the formulations with different Paclitaxel contents while fixing the weight ratio of monoolein:tricaprylin:Tween 80 to 55.0:27.5:16.5 by weight (G1, G2, G3 and G4 in Table 3, Figure 4D). Bioavailability was $13 \%$ and $14 \%$ when the concentration of paclitaxel was 0.5 and $1 \%(\mathrm{w} / \mathrm{w})$, respectively, in the formulation. When the concentration was 1.5 and $2.0 \%(\mathrm{w} / \mathrm{w})$, bioavailability decreased with increasing paclitaxel dose and was $4 \%$ and $2 \%$, respectively.

\subsection{Fasting vs. non-fasting conditions}

When the formulation is given orally, the fullness of stomach can influence the pharmacokinetics of the administered drug. Throughout the experiments, we administered the oral formulations after $8 \mathrm{~h}$ of fasting. In G5, however, we fed DHP107 to mice with free access to food and water before and after the drug administration in order to observe the influence of stomach emptiness on the absorption of the drug. Under the non-fasting condition, $C_{\max }$ increased to $3.4 \mu \mathrm{g} / \mathrm{ml}$ when compared to the fasting condition $(2.0 \mu \mathrm{g} / \mathrm{ml})$ and $\mathrm{T}_{\max }$ was reduced to $1 \mathrm{~h}$ (Figure 4E). The AUC values for non-fasting and fasting conditions were $15.3(20 \% \mathrm{BA})$ and $11.0 \mu \mathrm{g} \cdot \mathrm{h} / \mathrm{ml}(14 \% \mathrm{BA})$, respectively. We could conclude that the food in the gastrointestinal tract did not interfere with, but rather helped the absorption of paclitaxel. 


\subsection{Crystalline vs. amorphous paclitaxel}

The formulations made with crystalline and amorphous paclitaxel were administered orally to mice (Figure 4F). The pharmacokinetic profiles were virtually identical for these two formulations. We expected that the crystallinity of the drug would not affect the degree of oral absorption since paclitaxel was dissolved completely in tricaprylin/dichloromethane mixture before adding other ingredients, and therefore, the final products would be identical.

\subsection{Formulation without Tween 80}

Oral formulations with (G2, DHP107, Table 3) or without Tween 80 (G7) were prepared. Pharmacokinetic profiles were different for these two formulations (Figure 4G). When the formulation without Tween 80 was administered, $\mathrm{T}_{\max }$ was $1 \mathrm{~h}$ instead of 3 , and the AUC value was reduced to $6.3 \mu \mathrm{g} \cdot \mathrm{h} / \mathrm{ml}$, which was ca. $56 \%$ of that for DHP107.

\subsection{Oral administration of the aqueous dispersions of DHP107}

Even though our oral paclitaxel formulations including DHP107 can be taken per se, they can also be mixed with water or taste-masking syrups for administration. To examine how the absorption of paclitaxel changes upon feeding the dispersion, DHP107 was mixed with water or syrup at 3:7 by weight. DHP107 was dispersed spontaneously in water to produce emulsion droplets having average diameter of 6-8 $\mu \mathrm{m}$. By vortexing the mixture of DHP107 and water or syrup for $1 \mathrm{~min}$, the diameters of emulsion droplets were reduced to 6 (polydispersity $=1$ ) or 3 (polydispersity $=1$ ) $\mu \mathrm{m}$, respectively. By sonicating DHP107/water mixture at $180 \mathrm{KW}$ for $1 \mathrm{~min}$, we also obtained the dispersion with the oil droplets having $1.4 \mu \mathrm{m}$ (polydispersity $=1$ ) in diameter.

When the dispersions were orally administered, pharmacokinetic profiles did not change significantly except for the fact that the AUC values were reduced to $c a .40 \sim 70 \%$ of the original G2 formulation.

\subsection{Antitumor efficacy of DHP107 in experimental animals}

To evaluate the antitumor activity of DHP107 in mice, suspension of NCI-H358 cells was injected subcutaneously to Balb/c athymic mice. All of the mice inoculated with the human non-small cell lung cancer cells developed progressively growing tumors. The mice were administered orally with DHP107 (G2, $50 \mathrm{mg} / \mathrm{kg})$ or intravenously with Taxol ${ }^{\circledR}(10 \mathrm{mg} / \mathrm{kg})$ for 5 consecutive days 10 days after the inoculation. The entire tumor tissue was removed surgically after the experiment and photographed as shown in Figure 5A. In the group administered with oral DHP107 and intravenous Taxol ${ }^{\circledR}$, the tumor size was reduced gradually from ca. 100 to $15 \pm 3$ and $19 \pm 5 \mathrm{~mm}^{3}$, respectively, in ca. 25 days after the administration of the drug and remained unchanged for the duration of the experiment (Figure 5B). The tumor size data for these two groups were indifferent statistically. In the control group administered orally with the vehicle only, the tumor grew continuously to $c a .360 \pm 20 \mathrm{~mm}^{3}$ in 45 days.

\section{Discussion}

In current study, we prepared oil formulations for oral administration of paclitaxel and examined their physical properties, pharmacokinetic profiles and antitumor activities. 

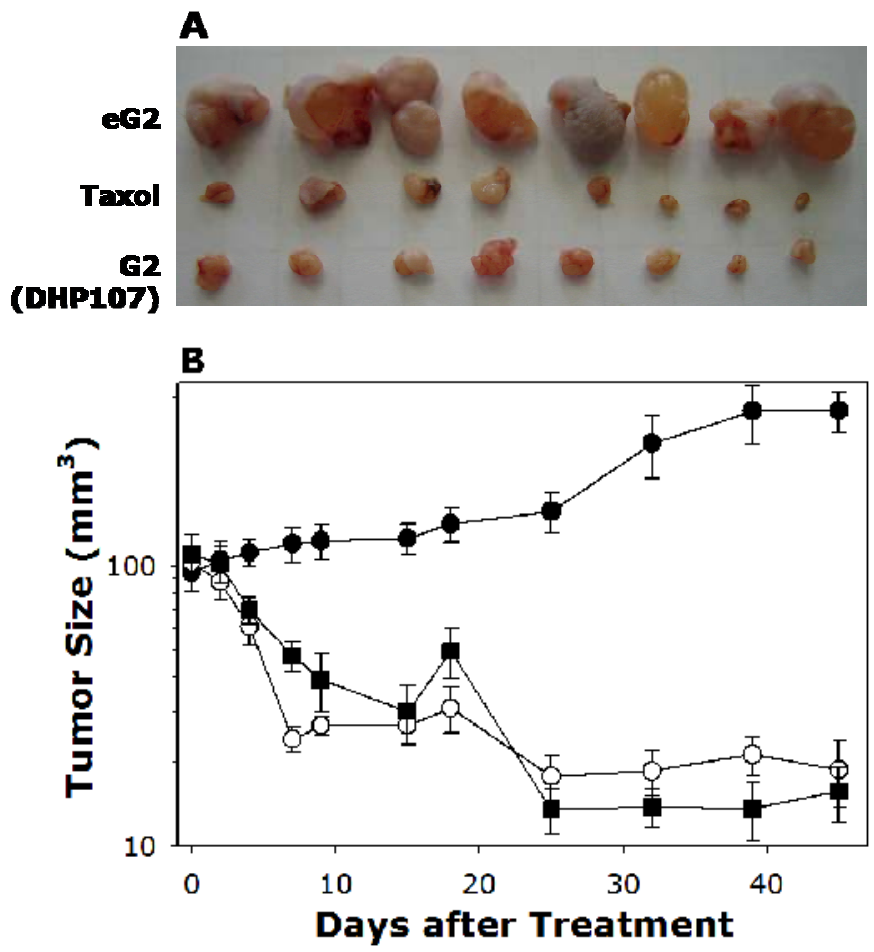

Fig. 5. Antitumor activity of DHP107 in male Balb/c athymic mice, subcutaneously injected with suspension of NCI-H358 cells $\left(1.2 \times 10^{7}\right.$ cells/mouse). A) The entire tumor tissue removed surgically after the experiment. B) The volume of tumor for the oral vehicle control $(\mathrm{eG} 2, \mathbf{O})$, intravenous $\operatorname{Taxol}^{\circledR}(\mathrm{O}, 10 \mathrm{mg} / \mathrm{kg})$ and oral DHP107 $(\mathrm{G} 2, \mathbf{\square}, 50 \mathrm{mg} / \mathrm{kg})$.

Paclitaxel was commercially available in at least two different polymorphs. Amorphous paclitaxel was readily soluble in our oral formulations at $10 \mathrm{mg} / \mathrm{ml}$ when sonicated for $30 \mathrm{~s}$. Crystalline paclitaxel, on the other hand, did not dissolve in the oily formulations directly. We had to dissolve crystalline paclitaxel in the tricaprylin/methylene chloride mixture completely, and to remove the solvent in turn to obtain the oily solution of paclitaxel/tricaprylin before adding monoolein and Tween 80 . Even though paclitaxel could also be dissolved in methylene chloride/tricaprylin/monoolein/Tween 80 as well as in methylene chloride/tricaprylin, monoolein and Tween 80 were not added to the mixture until after evaporating the solvent to minimize the oxidation of these materials containing unsaturated hydrocarbons. Pharmacokinetic study showed that AUC values were identical statistically when paclitaxel from different vendors or different preparation processes was used (Figure 4F).

DSC study was performed for the formulations with different triglycerides. In the heating thermograms, two endothermic transitions were observed corresponding to the chain melting transitions of monoolein and triglycerides for T8 and T12 formulations. Chain melting transition of triacetin, tributyrin and tricaproin were not observed since the phase transition temperatures of these triglycerides were below $0{ }^{\circ} \mathrm{C}$. There was only a single endothermic transition for the tricaprin/monoolein mixture at the weight ratio of 2:1 since 
they formed a eutectic mixture (Roh et al., 2004). The phase behavior of monoolein and triglycerides could be explained by the classical binary eutectic phase diagram of two immiscible solid phases and a completely miscible melt.

We could conclude from the DSC data that monoolein and tricaprylin do not mix below $c a .30$ ${ }^{\circ} \mathrm{C}$ where monoolein exists as lamellar crystalline phase. Monoolein and Tween 80 did not mix in this temperature range either. Above $30{ }^{\circ} \mathrm{C}$, however, all three ingredients, tricaprylin, monoolein and Tween 80 existed as liquid and mixed homogeneously. Two important things to note were that paclitaxel precipitates were not observed even at $0{ }^{\circ} \mathrm{C}$ by microscopy in any of the oral formulations and that the formulations could be heated and cooled in cycles between -20 and $40{ }^{\circ} \mathrm{C}$ without compromising the effectiveness of the drug. These results are significant in that the oral formulation (possibly in a soft capsule) can be stored in the shelf and orally administered in the phase-separated form, but transforms into a homogenous liquid solution by the body heat while traveling inside the gastrointestinal tract.

In our oral formulations, monoolein was included due to its well-known mucoadhesive property (Nielsen et al., 1998). Monoolein and other monoglycerides have been used in oral drug delivery formulations since they can enhance absorption of small molecules and even proteins through the epithelial cells (Ganem-Quintanar et al., 2000; Chung et al., 2002). The absorption enhancing mechanism is not clearly known. Nanopore induction or the membrane perturbation (Anderson, 2005), and the intermediate phases formed in the intestine (Kossena et al., 2005) were considered important. In vitro study showed that monoglycerides can enhance the cellular absorption of drugs by inhibition of Pglycoproteins (Konishi et al., 2004). Further studies are required to explain the absorption enhancing mechanism of monoolein unequivocally.

In the previous study, we administered intravesically the dispersion of DHP107 in water to experimental rabbits and observed that the formulation adhered tightly to the bladder mucosa, and paclitaxel penetrated through the physical barrier imposed by the uroepithelium (S. J. Lee et al., 2005). Histological examination of the bladder and other tissues did not reveal any local or systemic toxicity to the rabbits.

Oral administration of formulations containing different triglycerides showed that those with tricaproin, tricaprylin and tricaprin had higher AUC values than others. The formulation with tricaproin had the highest AUC value. We must note that paclitaxel was mixed directly with the vehicles and sonicated for $30 \mathrm{~s}$ to obtain the formulations in Table 2. When the preparation process was changed to add and to remove methylene chloride in turn in order to solubilize crystalline as well as amorphous paclitaxel, the AUC value of tricaprylin/monoolein/Tween 80 / paclitaxel formulation (G2, DHP107) increased from 8.9 to $11.0 \mu \mathrm{g} \mathrm{h} / \mathrm{ml}$, which was similar to that of tricaproin/monoolein/Tween 80/paclitaxel formulation in Table 2 (T6) statistically. We proceeded with the tricaprylin/monoolein/Tween $80 /$ paclitaxel formulation for further experiments because the toxicity of tricaprylin (LD50 $=3700 \mathrm{mg} / \mathrm{kg}$; intravenous and 26600 $\mathrm{mg} / \mathrm{kg}$; oral) was much lower than that of tricaproin (LD50 $=122 \mathrm{mg} / \mathrm{kg}$; intravenous) for mice according to the Material Safety Data Sheets for tricaprylin (T9126) and tricaproin (T4137) provided by Sigma (www.sigma-aldrich.com).

We also performed the pharmacokinetic study with the formulations having different contents of the drug, under fasting or non-fasting conditions, by changing the commercial source of paclitaxel, with or without the emulsifier, Tween 80 and in the form of dispersions 
in syrup or in water. From these experiments, we could conclude that the optimum concentration of paclitaxel in the formulation was $10 \mathrm{mg} / \mathrm{ml}$, and the tricaprylin/monoolein/Tween 80/paclitaxel formulation was the most effective when given directly to the non-fasting animals. Under the fasting conditions, $T_{\max }$ was $3 \mathrm{~h} . \mathrm{T}_{\max }$, however, was $1 \mathrm{~h}$ when the animal had free access to food and water. In a separate experiment, we observed that the bile salts helped the micronization and micellization of DHP107. It is possible that the micronization process of DHP107 was fastened by the secreted bile salts already existing under the non-fasting condition. When the formulation was fed to the empty stomach, on the other hand, bile salt secretion would start after the oily DHP107 reaches the upper intestine.

Our liquid type formulations were very effective in delivering paclitaxel orally, easy to prepare, biocompatible, and physically stable. Preclinical studies have demonstrated superior antitumor efficacy and high bioavailability. Most notably, the blood paclitaxel concentration was high after the oral administration even though the P-glycoprotein inhibitors were not coadministered when compared to the formulations reported in the literature (Table 1). The results show that the blood paclitaxel concentration reached as high as $c a .3 \mu \mathrm{g} / \mathrm{ml}$ and higher than $1 \mu \mathrm{g} / \mathrm{ml}$ for $4 \sim 6$ hours in Balb/c mice after oral administration of $50 \mathrm{mg} / \mathrm{kg}$ of paclitaxel dose. Also the bioavailability of paclitaxel was $c a .14 \%$ and $20 \%$ when compared to Taxol ${ }^{\circledR}$ injection under fasting and non-fasting conditions, respectively.

Antitumor experiment also showed that the tumor regression rate of the oral DHP107 group $(50 \mathrm{mg} / \mathrm{kg})$ was similar to that of the intravenous Taxol${ }^{\circledR}$ group $(10 \mathrm{mg} / \mathrm{kg})$. Also, the tumor size of an established non-small cell lung cancer was significantly reduced after the oral treatment. Considering that the bioavailability of DHP107 was ca. $14 \sim 20 \%$ compared to Taxol ${ }^{\circledR}$ injection, similar regression rate was expected to a degree.

\section{Conclusions}

In conclusion, we prepared oral paclitaxel formulations that do not contain P-glycoprotein inhibitors as active pharmaceutical ingredients. The formulations are liquid at body temperature and can solubilize paclitaxel effectively. The oral bioavailability of paclitaxel was $14 \sim 20 \%$ when compared to the intravenous Taxol ${ }^{\circledR}$ formulation without concomitant administration of P-glycoprotein inhibitors. Preclinical efficacy study on mice showed that the tumor size was reduced significantly for the human non-small cell lung carcinoma. In separate studies, we have determined the tissue distribution of paclitaxel after oral administration (manuscript in preparation) and performed pre-clinical antitumor efficacy studies in mice with several tumor types (manuscript in preparation). Regulatory preclinical experiments to initiate the clinical evaluations of DHP107 have also been carried out.

\section{References}

Anderson, D. (2005) Reversed liquid crystalline phases with non-paraffin hydrophobes. European Patent 1539099A2, 2005

Bardelmeijer, H. A., Beijnen, J. H., Brouwer, K. R., Rosing, H., Nooijen, W. J., Schellens, J. H. M., \& van Tellingen, O. (2000) Increased oral bioavailability of paclitaxel by GF120918 in mice through selective modulation of P-glycoprotein. Clin. Cancer Res., Vol. 6. pp. 4416-4421 
Bardelmeijer, H. A., Ouwehand, M., Beijnen, J. H., Schellens, J. H. M,. \& van Tellingen, O. (2004) Efficacy of novel P-glycoprotein inhibitors to increase the oral uptake of paclitaxel in mice. Inves. New Drugs, Vol. 22. pp. 219-229

Briggs, J., Chung, H., \& Caffrey, M. (1996) The temperature-composition phase diagram and mesophase structure characterization of the monoolein/water system. J. Phys. II France, Vol. 6. pp. 723-751

Choi, J. S., \& Li, X. (2005) The effect of verapamil on the pharmacokinetics of paclitaxel in rats. Eur. J. Pharm. Sci., Vol. 24. pp. 95-100

Choi, J. -S., Choi, H. -K., \& Shin, S. -C. (2004) Enhanced bioavailability of paclitaxel after oral coadministration with flavone in rats. Int. J. Pharm., Vol. 275. pp. 165-170

Choi, J. -S., Jo, B. -W., \& Kim, Y. -C. (2004) Enhanced paclitaxel bioavailability after oral administration paclitaxel or prodrug to rats pretreated with quercetin. Eur. J. Pharm. Biopharm., Vol. 57. pp. 313-318

Chung, H., Kim, J.-s., Um, J. Y., Kwon, I. C., \& Jeong, S. Y. (2002) Self-assembled "nanocubicle" as a carrier for peroral insulin delivery. Diabetologia, Vol. 45. pp. 448-451

Chung, H., Kim, T. W., Kwon, M., Kwon, I. C., \& Jeong, S. Y. (2001) Oil components modulate physical characteristics and function of the natural oil emulsions as drug or gene delivery system. J. Control. Rel., Vol. 71. pp. 339-350

Clogston, J., Craciun, G., Hart D.J., \& Caffrey, M. (2005) Controlling release from the lipidic cubic phase by selective alkylation. J. Cont. Rel., Vol. 102. pp. 441-461

Clogston, J., \& Caffrey, M. (2005) Controlling release from the lipidic cubic phase. Amino acids, peptides, proteins and nucleic acids. J. Cont. Rel., Vol. 107. pp. 97-111

Clogston, J., Rathman, J., Tomasko, D., Walker, H., \& Caffrey, M. (2000) Phase behavior of a monoacylglycerol (Myverol 18-99K)/water system. Chem. Phys. Lipids, Vol. 107. pp. 191-220

Ganem-Quintanar, A., Quintanar-Guerrero, \& D., Buri, P. (2000) Monoolein: A review of pharmaceutical applications. Drug Dev. Indust. Pham., Vol. 26. pp. 809-820

Gao, P., Rush, B. D., Pfund, W. P., Huang, T., Bauer, J. M., Morozowich, W., Kuo, M. -S., \& Hageman, M. J. (2003) Development of a supersaturable SEDDS (S-SEDDS) formulation of paclitaxel with improved oral bioavailability. J. Pharm. Sci., Vol. 92. pp. 2386-2398

Garber, K. (2004) Improved paclitaxel formulation hints at new chemotherapy approach. J. Natl. Cancer Inst., Vol. 96. pp. 90-91

Gianni, L., Kearns, C. M., Giani, A., Capri, G., Vigano, L., Lacatelli, A., Bonadonna, G., \& Egorin, M. J. (1995). Nonlinear pharmacokinetics and metabolism of paclitaxel and its pharmacokinetic/pharmacodynamic relationships in humans. J. Clin. Oncol., Vol. 13. pp. 180-190

Hennenfent, K. L., \& Govindan, R. (2006) Novel formulations of taxanes: a review. Old wine in a new bottle? Ann. Oncol., Vol. 17. pp. $735-749$

Hong, J. W., Lee, I. H., Kwok, Y. H., Park, Y. T., Kwon, I. C., Jeong, S. Y., \& Chung, H. (2004) The tissue distribution of paclitaxel after peroral administration of mucoadhesive formulation, Proceedings of Controlled Release Society 31st Annual Meeting, Honolulu, HA, 2004

Huizing, M. T., Giaccone, G., Van Warmerdam, L. J. C., Rosing, H., Bakker, P. J. M., Vermorken, J. B., Postmus, P. E., Zandwijk, N., van Koolen, M. G. J., ten Bokkel Huinink, W. W., van der Vijgh, W. J., Bierhorst, F. J., Lai, A., Dalesio, O., Pinedo, H. M., Veenhof, C. H., \& Beijnen, J. H. (1997) Pharmacokinetics of paclitaxel and 
carboplatin in a dose escalating and dose sequencing study in patients with non small cell lung cancer. J. Clin. Oncol., Vol. 15. pp. 317-329

Ibrahim, N. K., Desai, N., Legha, S., Soon-Shiong, P., Theriault, R. L., Rivera, E., Esmaeli, B., Ring, S. E., Bedikian, A., Hortobagyi, G. N., \& Ellerhorst, J. A. (2002) Phase I and pharmacokinetic study of ABI-007, a Cremophor-free, protein-stabilized, nanoparticle formulation of paclitaxel. Clin. Cancer Res., Vol. 8. pp. 1038-1044

Kan, P., Chen, Z. B., Lee, C. J., \& Chu, I. M. (1999) Development of nonionic surfactant/ phospholipids o/w emulsion as a paclitaxel delivery system. J. Control. Rel., Vol. 58. pp. 271- 278

Kearns, C. M., Gianni, L., \& Egorin, M. J. (1995). Paclitaxel pharmacokinetics and pharmacodynamics. Semin. Oncol., Vol. 3. pp. 16-23

Kim, D. W., Kwon, J. S., Kim, Y. G., Kim, M. S., Lee, G. S., Youn, T. J., \& Cho, M. -C. (2004) Novel oral formulation of paclitaxel inhibits neointimal hyperplasia in a rat carotid artery injury model. Circulation, Vol. 109. pp. 1558-1563

Kim, J.-H., Kim, Y.-S., Kim, S., Park, J. H., Kim, K., Choi, K., Chung, H., Jeong, S. Y., Park, R.W., Kim, I.-S., \& Kwon, I. C. (2006) Hydrophobically modified glycol chitosan nanoparticles as carriers for paclitaxel. J. Cont. Rel., Vol. 111. pp. 228-234

Konishi, T., Satsu, H., Hatsugai, Y., Aizawa, K., Inakuma, T., Nagata, S., Sakuda, S.-h., Nagasawa, H., \& Shimizu, M. (2004) Inhibitory effect of a bitter melon extract on the P-glycoprotein activity in intestinal Caco-2 cells. Brit. J. Pharm., Vol. 143. pp. 379-387

Kossena, G. A., Charman, W. N., Boyd, B. J., \& Porter, C. J. H. (2005) Influence of the intermediate digestion phases of common formulation lipids on the absorption of a poorly water-soluble drug. J. Pharm. Sci., Vol. 94. pp. 481-492

Lee, I. H., Hong, J. W., Y. H., Kwak, Y. H., Park, Y. T., Kwon, I. C., Jeong, S. Y., \& Chung, H. (2004) Oral paclitaxel delivery systems, Proceedings of Controlled Release Society 31st Annual Meeting, Honolulu, HA, 2004

Lee, I.-H., Park, Y. T., Roh, K., Chung, H., Kwon, I. C., \& Jeong, S. Y. (2005) Stable paclitaxel formulations in oily contrast medium. J. Cont. Rel., Vol. 102. pp. 415-425

Lee, J. H., Gi, U.-S., Kim, J.-H., Kim, Y., Kim, S.-H., Oh, H., \& Min, B. (2001) Preparation and characterization of solvent induced dihydrated, anhydrous, and amorphous paclitaxel. Bull. Korean Chem. Soc., Vol. 22. pp. 925-928

Lee, S.-J., Kim, S. W., Chung, H., Park, Y. T., Choi, Y. W., Cho, Y.-H., \& Yoon, M. S. (2005) Bioadhesive drug delivery system using glyceryl monooleate for the intravesical administration of paclitaxel. Chemotherapy, Vol. 51. pp. 311-318

Liggins, R.T., Hunter, W. L., \& Burt, H. M. (1997) Solid-state characterization of paclitaxel. J. Pharm. Sci., 86 pp. 1458-1463

Meerum Terwogt, J. M., Malingre, M. M., Beijnen, J. H., ten Bokkel Huinink, W. W., Rosing, H., Koopman, F. J., van Tellingen, O., Swart, M., \& Schellens, J. H. M. (1999) Coadministration of oral cyclosporin A enables oral therapy with paclitaxel. Clin. Cancer Res., Vol. 5. pp. 3379- 3384

Nielsen, L. S., Schubert, L., \& Hansen, J. (1998) Bioadhesive drug delivery systems. I. Characterisation of mucoadhesive properties of systems based on glyceryl monooleate and glyceryl monolinoleate. Eur. J. Pharm. Sci., Vol. 6. pp. 231-239

Peltier, S., Oger, J.-M., Lagarce, F., Couet, W., Benoît, J.-P. (2006) Enhanced oral paclitaxel bioavailability after administration of paclitaxel-loaded lipid nanocapsules. Pharm. Res., Vol. 23. pp. 1243-1250

Pfeifer, R.W., Hale, K.N., Cronquist, \& S. E., Daniels, M. (1993) Precipitation of paclitaxel during infusion by pump. Am. J. Hosp. Pharm., Vol. 50. pp. 2518-2521 
Qiu, H., \& Caffrey, M. (2000) The phase diagram of the monoolein/water system: metastability and equilibrium aspects. Biomaterials, Vol. 21. pp. 223-234

Roh, K. H., Lee, S. Y., Kwon, I. C., Jeong, S. Y., \& Chung, H. (2004) Hydrophilic polymers stabilize eutectic mixture of monoglyceride and triglyceride. Proceedings of Biophysical Society 48th Annual Meeting, Baltimore, MD, 2004

Rowinsky, E. K. \& Donehower, R. C. (1995). Paclitaxel (Taxol), N. Engl. J. Med., Vol. 332. pp. 1004-1014

Schellens, J. H. M., Malingre, M. M., Kruijtzer, C. M. F., Bardelmeijer, H. A., van Tellingen, O., Schinkel, A. H., \& Beijnen, J. H. (2000) Modulation of oral bioavailability of anticancer drugs: from mouse to man. Eur. J. Pharm. Sci., Vol. 12. pp. 103-110

Shin, B. S., Kim, H. J., Hong, S. H., Lee, J. B., Hwang, S. W., Lee, M. H., \& Yoo, S. D. (2009) Enhanced absorption and tissue distribution of paclitaxel following oral administration of DHP 107, a novel mucoadhesive lipid dosage form. Cancer Chemoth. Pharm. Vol. 64. Pp. 87-94

Singla, A. K., Garg, A., \& Aggarwal, D. (2002) Paclitaxel and its formulations. Int. J. Pharm., Vol. 235. pp. 179-192

Sparreboom, A., Van Asperen, J., Mayer, U., Schinkel, A. H., Smit, J. W., Meijer, D. K. F., Borst, P., Nooijen, W. J., Beijnen, J. H., \& Van Tellingen, O. (1997) Limited oral bioavailability and active epithelial excretion of paclitaxel (Taxol) caused by Pglycoprotein in the intestine. Proc. Natl. Acad. Sci. USA, Vol. 94. pp. 2031-2035

Sparreboom, A., van Tellingen, O., Nooijen, W. J., \& Beijnen, J. H. (1996) Nonlinear pharmacokinetics of paclitaxel in mice results from the pharmaceutical vehicle Cremophor EL. Cancer Res., Vol. 56. pp. 2112-2115

Sugahara, S.-i., Kajiki, M., Kuriyama, H., \& obayashi, T.-r. (2007) Complete regression of xenografted human carcinomas by a paclitaxel-carboxymethyl dextran conjugate (AZ10992). J. Cont. Rel., Vol. 117. pp. 40-50

van Asperen, J., van Tellingen, O., Sparreboom, A., Schinkel, A. H., Borst, P., Nooijen, W. J., Beijnen, J. H. (1997) Enhanced oral bioavailability of paclitaxel in mice treated with the P-glycoprotein blocker SDZ PSC 833. Br. J. Cancer, Vol. 76. pp. 1181-1183

Van Asperen, J., van Tellingen, O., van der Valk, M. A., Rozenhart, M., \& Beijnen, J. H. (1998) Enhanced oral absorption and decreased elimination of paclitaxel in mice cotreated with cyclosporine A. Clin. Cancer Res., Vol. 4. pp. 2293-2297

Weiss, R. B., Donehower, R. C., Wiernik, P. H. T., Ohnuma, R. J., Trump, D. L., Baker Jr, J. R., Van Echo, D. A., Von Hoff, D. D. \& Leyland-Jones, B. (1990). Hypersensitivity reactions from taxol, J. Clin. Oncol., Vol. 8. pp. 1263-1268

Woo. J. S., Lee, C. H., Shim, C. K., \& Hwang, S. -J. (2003) Enhanced oral bioavailability of paclitaxel by coadministration of the P-glycoprotein inhibitor KR30031. Pharm. Res., Vol. 20. pp. 24-30

Xie, Z., Guan, H., Chen, X., Lu, C., Chen, L., Hu, X., Shi, Q., \& Jing, X. A (2007) novel polymer-paclitaxel conjugate based on amphiphilic triblock. J. Cont. Rel., Vol. 117. pp. $210-216$

Yang, S., Gursoy, R. N., Lambert, G., \& Benita, S. (2004) Enhanced oral absorption of paclitaxel in a novel self-microemulsifying drug delivery system with or without concomitant use of P-glycoprotein inhibitors. Pharm. Res., Vol. 21. pp. 261-270

Yoon, C. J., Chung, J. W., Park, J. H., Yoon, Y. H., Lee, J. W., Jeong, S. Y., \& Chung, H. (2003) Transcatheter arterial chemoembolization with paclitaxel-lipiodol solution in rabbit VX2 liver tumor. Radiology, Vol. 229. pp. 126-131 


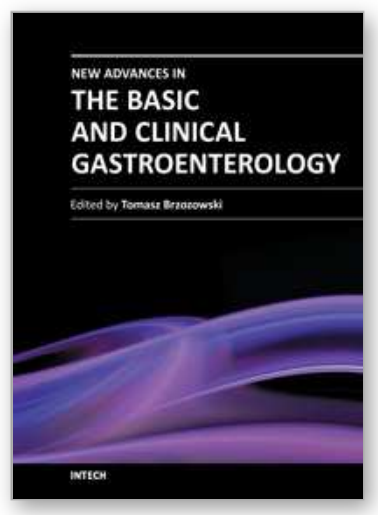

\author{
New Advances in the Basic and Clinical Gastroenterology \\ Edited by Prof. Tomasz Brzozowski
}

ISBN 978-953-51-0521-3

Hard cover, 546 pages

Publisher InTech

Published online 18, April, 2012

Published in print edition April, 2012

The purpose of this book was to present the integrative, basic and clinical approaches based on recent developments in the field of gastroenterology. The most important advances in the pathophysiology and treatment of gastrointestinal disorders are discussed including; gastroesophageal reflux disease (GERD), peptic ulcer disease, irritable bowel disease (IBD), NSAIDs-induced gastroenteropathy and pancreatitis. Special focus was addressed to microbial aspects in the gut including recent achievements in the understanding of function of probiotic bacteria, their interaction with gastrointestinal epithelium and usefulness in the treatment of human disorders. We hope that this book will provide relevant new information useful to clinicians and basic scientists as well as to medical students, all looking for new advancements in the field of gastroenterology.

\title{
How to reference
}

In order to correctly reference this scholarly work, feel free to copy and paste the following:

In-Hyun Lee, Jung Wan Hong, Yura Jang, Yeong Taek Park and Hesson Chung (2012). Development, Optimization and Absorption Mechanism of DHP107, Oral Paclitaxel Formulation for Single-Agent Anticancer Therapy, New Advances in the Basic and Clinical Gastroenterology, Prof. Tomasz Brzozowski (Ed.), ISBN: 978-953-51-0521-3, InTech, Available from: http://www.intechopen.com/books/new-advances-in-the-basicand-clinical-gastroenterology/development-optimization-and-absorption-mechanism-of-dhp107-oral-paclitaxelformulation-for-single-a

\section{INTECH}

open science | open minds

\section{InTech Europe}

University Campus STeP Ri

Slavka Krautzeka 83/A

51000 Rijeka, Croatia

Phone: +385 (51) 770447

Fax: +385 (51) 686166

www.intechopen.com

\section{InTech China}

Unit 405, Office Block, Hotel Equatorial Shanghai

No.65, Yan An Road (West), Shanghai, 200040, China

中国上海市延安西路65号上海国际贵都大饭店办公楼 405 单元

Phone: +86-21-62489820

Fax: $+86-21-62489821$ 
(C) 2012 The Author(s). Licensee IntechOpen. This is an open access article distributed under the terms of the Creative Commons Attribution 3.0 License, which permits unrestricted use, distribution, and reproduction in any medium, provided the original work is properly cited. 